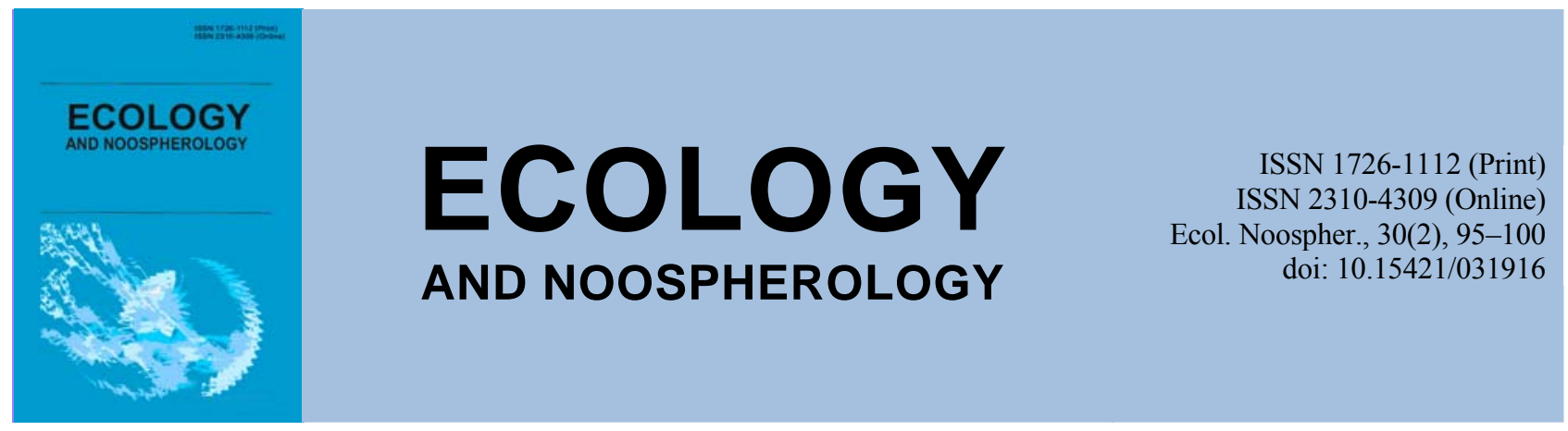

\title{
Destruction of toluene and xylene by sulfate-reducing bacteria
}

\author{
N. S. Verkholiak, T. B. Peretyatko \\ Ivan Franko National University of Lviv, Lviv, Ukraine
}

Article info

Received 11.09.2019

Received in revised form 17.09.2019

Accepted 26.09.2019

Ivan Franko National University of Lviv, Hrushevsky str., 4, Lviv, 79005, Ukraine.

Tel.: +38-096-271-13-78

E-mail:

nataljaverkholjak@gmail.com
Verkholiak, N. S., Peretyatko, T. B. (2019). Destruction of toluene and xylene by sulfate-reducing bacteria. Ecology and Noospherology, 30(2), 95-100. doi:10.15421/031916

As a result of human activity aromatic hydrocarbons enter the environment in large quantities, contaminating it. Dropping of insufficiently treated wastewater drains considerably decrease the quality of water. Quite effective biological methods of purification of contaminated environment are the usage of microorganisms. Prospective microorganisms for sewage treatment are sulfatereducing bacteria. The purpose of the work was to investigate the ability of sulfate-reducing bacteria to use xylene and toluene as a source of carbon under different cultivation conditions. The study objects were sulfate-reducing bacteria Desulfotomaculum AR1 and Desulfovibrio desulfuricans Ya-11. The biomass of bacteria was determined turbidimetrically, the content of sulfate ion and hydrogen sulfide - photometrically in the culture fluid. The content of fumarate was determined by the method of high-performance liquid chromatography. The ability of Desulfotomaculum AR1 and D. desulfuricans Ya-11 bacteria to use toluene and xylene as the sole source of carbon and energy has been established. In the toluene environment, a better growth of bacteria was observed. A comparison was made between the efficiency of the reduction of sulfate ions and the growth of bacteria in the control medium and the medium with aromatic compounds. The efficiency of sulfate ions reduction was sufficiently high in the control medium, whereas in the toluene/xylene media the efficiency of sulfate utilization and hydrogen sulfide accumulation was lower compared to the control parameters. The growth of Desulfotomaculum AR1 and D. desulfuricans Ya-11 sulfate-reducing bacteria was investigated in xylene and toluene media in the presence/absence of fumarate. According to the results of the studies, the best growth of the tested bacteria was observed in the medium with aromatic compounds in the presence of fumarate and sulfate ion. Efficiency of use of fumarate in the medium with toluene with bacteria Desulfotomaculum AR1 was more than $90 \%$. Fumarate can be used by sulfate-reducing bacteria as a source of carbon, donor and acceptor of electrons. Fumarate is most likely to inhibit sulfate reduction in Desulfotomaculum AR1 and $D$. desulfuricans Ya-11 bacteria, as indicated by studies showing that sulfate reduction efficiency in lactate, fumarate, and sulfate ion media was half that of control. Sulfate-reducing bacteria are capable to anaerobically degrade aromatic hydrocarbons in the presence of sulfate ions as terminal electron acceptors. The ability of sulfate-reducing bacteria Desulfotomaculum AR1 and D. desulfuricans Ya-11 to use the aromatics of the BTEX toluene, xylene and sulfate-ions, makes them promising at the biological purification step of contaminated wastewater from these pollutants.

Keywords: toluene; xylene; sulfate-reducing bacteria; destruction; xenobiotics; sulfate ion; aromatic compounds

\section{Деструкція толуену та ксилену сульфатвідновлювальними бактеріями}

\author{
Н. С. Верхоляк, Т. Б. Перетятко
}

Львівський національний університет імені Івана Франка, Львів, Украӥна

Основними мінералізаторами органічної речовини у природі є бактерії. У статті наведено результати досліджень здатності сульфатвідновлювальних бактерій Desulfotomaculum AR1, виділених із системи очищення стічних вод м. Львова, та D. desulfuricans Yа-11, виділених з озера Яворівське, використовувати толуен та ксилен як єдине джерело карбону та енергії. Досліджено ефективність відновлення сульфат-йонів за росту бактерій у середовищах з ароматичними сполуками. Показано результати впливу фумарату на нагромадження біомаси бактерій за досліджуваних умов та ефективність 
використання фумарату мікроорганізмами. Завдяки здатності досліджуваних штамів бактерій Desulfotomaculum AR1 та D. desulfuricans Ya-11 використовувати ароматичні сполуки групи БТЕК та сульфат-йони їх можна застосовувати 3 метою очищення забрудненого водного середовища від цих ксенобіотиків за анаеробних умов.

Ключові слова: толуен; ксилен; сульфатвідновлювальні бактерії; деструкція; ксенобіотики; сульфат-йон; ароматичні сполуки

\section{Вступ}

Одними з найбільш стійких ксенобіотиків у природі $є$ ароматичні вуглеводні, які широко використовують у промисловості та сільському господарстві (Salmanov et al., 2010). Унаслідок діяльності людини ароматичні вуглеводні постійно надходять i накопичуються в зовнішньому середовищі. Надходження у водойми недостатньо очищених стоків значно погіршує якість води і стан водойм у цілому (Pavlenko et al., 2007).

Пошуки ефективних способів очищення довкілля від ароматичних сполук $є$ актуальною проблемою сьогодення. Дедалі частіше перевагу надають біологічним методам очищення забруднених територій, зокрема, за участю мікроорганізмів, які завдяки фізіологічним і генетичним особливостям швидко реагують на зміни складу середовища і на дію стресових чинників (Sushko et al., 2016).

Мікроорганізми можуть розкладати ксенобіотики, що дає змогу вирішити низку екологічних проблем, пов'язаних 3 використанням пестицидів і зі скиданням промислових стоків. Активні «місцеві» культури мікроорганізмів, адаптовані до конкретних абіотичних умов, можуть бути використані як для очищення стічних вод, так і для інтенсифікації процесів ремедіації екосистем у разі постійного забруднення (Salmanov et al., 2010).

Агентство 3 охорони навколишнього середовища США встановило, що ксенобіотики ароматичної природи належать до групи найнебезпечніших забруднювачів довкілля. За угодою Стокгольмської конвенції від 29 квітня 2011 року про заборону й обмеження використання токсичних хімічних сполук список стійких органічних забрудників нараховував 21 ксенобіотик, вісім 3 яких ароматичної природи (Pirog, Antonuk, Sofilkanich, 2016). Ця конвенція була підтримана багатьма країнами та низкою міжурядових організацій: Global Environment Fund (GEF), World Health Organization (WHO), Food and Agriculture Organization (FAO), United Nations Environment Programme (UNEP), United Nations Institute for Training and Research (UNITAR), United Nations Industrial Development Organization (UNIDO) (Dudnik, Yevtushenko, 2013).

Забруднення довкілля ароматичними сполуками нерідко виникає в анаеробних біотопах, що не містять достатньої кількості кисню, таких як водоносні горизонти, осадові водні відклади і затоплені грунти. За таких умов біодеградація сполук-забруднювачів здійснюється за участю анаеробних чи факультативно-анаеробних мікроорганізмів, що використовують альтернативні кисню акцептори електронів: нітрат-йон (денітрифікувальні мікроорганізми), сульфат-йон (сульфатвідновлювальні), $\mathrm{Fe}$ (III) (залізовідновлювальні мікроорганізми), $\mathrm{CO}_{2}$ (метаногени) тощо (Khomenkov et al., 2008).

Потенційна токсичність i забрудненість довкілля ароматичними вуглеводнями $\epsilon$ причиною пошуку мікроорганізмів, здатних розкладати ці сполуки. Багато досліджень спрямовано на дослідження 3 використання анаеробними мікроорганізмами моноароматичних сполук групи БТЕК (бензену, толуену, етилбензену та ксилену) (Gibson, Harwood, 2002).

Перспективними мікроорганізмами для очищення стічних вод від органічних і неорганічних речовин, на думку багатьох дослідників, $є$ сульфатвідновлювальні бактерії - анаеробні організми, що окиснюють молекулярний водень та органічні сполуки, використовуючи сульфат-йон як акцептор електронів. Ці бактерії $\epsilon$ однією 3 основних складових мікробних угрупувань стічних і дренажних вод, забруднених грунтів, побутових та промислових відходів (Baran et al., 2003; Gudz et al., 2011; Halushka, Peretjatko, Gudz, 2007).

Метою роботи було дослідити здатність сульфатвідновлювальних бактерій Desulfotomaculum AR1 та D. desulfuricans Ya-11 використовувати ксилен та толуен як джерело карбону та енергії за різних умов культивування.

\section{Матеріали та методи досліджень}

У роботі використано сульфатвідновлювальні бактерії Desulfovibrio desulfuricans Yа-11, виділені 3 озера Яворівське (Peretyatko, Hnatush, Gudz, 2006), та Desulfotomaculum AR1, виділені із системи очищення стічних вод м. Львова (Verkholiak, Peretyatko, 2018). Бактерії культивували у середовищі Постгейта $\mathrm{C}$ такого складу (г/л): калій дигідрофосфат - 0,5; амоній хлорид 1,0 ; натрій сульфат - 4,5; кальцій хлорид гексагідрат 0,06 ; магній сульфат гептагідрат - 0,06; натрій лактат - 6; дріжджовий екстракт - 1; ферум (II) сульфат гептагідрат 0,004 ; натрій цитрат дигідрат - 0,3; $\mathrm{pH}$ середовища - 7,6 (Postgate, 1984) та модифікованому середовищі Постгейта С без лактату 3 толуеном (2,6 г/л), ксиленом (2,6 г/л). Фумарат додавали у середовище як акцептор електронів у концентрації 6 г/л.

Біомасу визначали турбідиметрично на фотоелектроколориметрі КФК-3 ( $\lambda=340$ нм, кювета 3 мм). Вміст $\mathrm{SO}_{4}{ }^{2-}$ визначали турбідиметрично ( $\lambda=520$ нм, кювета 10 мм) після осадження барій хлоридом (HOST 26426-85, 1985). Як стабілізатор суспензії використовували гліцерин. Кількість гідроген сульфіду визначали в культуральній рідині колориметрично 3 використанням $n$-амінодиметиланіліндигідрохлориду ( $\lambda=665$ нм, кювета 30 мм) (Sugiyama, 2002).

Вміст фумарату визначали методом високоефективної рідинної хроматографії. Хроматографічна система складалася 3 двох помп Varian ProStar 210 (Agilent Technologies, Сінгапур), хроматографічної колонки Pursuits 5 C18 (Agilent Technologies, Нідерланди), 250×4,6 мм у модулі колонок Varian ProStar 500 (Agilent Technologies, Австралія), спектрофотометричного детектора 3 фотодіодною матрицею Varian ProStar 335 (Agilent Technologies, Австралія). Як рухому фазу використовували $0,2 \%$-ний водний розчин трифтороцтової кислоти (Fisher Scientific, HPLC grade, Великобританія) (розчинник A) та ацетонітрил (Honeywell|Riedel-de Haen, Chromasolv for HPLC gradient grade (Німеччина), розчинник Б). Хроматографічне розділення починали 3 розчинника А протягом 7 хв. Розділення продовжували в лінійному градієнті від 0 до $4 \%$ розчинника Б протягом наступних 3 хв, і до $50 \%$ розчинника Б протягом наступних 20 хв. Час зрівноваження становив 5 хв, перед наступним введенням зразка систему витримували з розчинником А 10 хв. Потік розчинника становив 1,5 мл/хв, об'єм зразка 20 мкл. Хроматограми записували за довжини хвилі 210 нм. Температура колонки становила $35^{\circ} \mathrm{C}$ (Kerem et al., 2004).

Статистичне оброблення результатів проводили 3 використанням програми Microsoft Excel. Результати представлені як середнє значення 3 поправкою на стандартну похибку $(\mathrm{M} \pm \mathrm{m})$. Достовірність даних і різниці між ними оцінювали за коефіцієнтом Стьюдента. Відмінність між величинами вважали достовірною, коли ймовірність різниці $\mathrm{P}<0,05$. 


\section{Результати та їх обговорення}

Основними мінералізаторами органічної речовини у природі $є$ бактерії. Здатність швидко адаптуватися до змінних умов навколишнього середовища, широкий набір ферментних систем дають змогу бактеріям використовувати різні органічні сполуки як джерело енергії та карбону і тим самим розщеплювати токсичні, канцерогенні та мутагенні речовини, зокрема й ароматичні вуглеводні (Pavlenko et al., 2007).

Мікроорганізми можуть повністю використовувати молекулу ароматичної сполуки як джерело карбону, або як джерело карбону та енергії за анаеробних умов (Gibson, Harwood, 2002).

Ефективність розкладання сполук групи БТЕК $є$ доволі нестійким і залежить від чисельності мікроорганізмів, здатних до деструкції ароматичних сполук та концентрації сполук. 3 компонентів групи БТЕК толуен найлегше розкладається за анаеробних умов (Gibson, Harwood, 2002). Ми дослідили здатність бактерій Desulfotomaculum AR1 та D. desulfuricans Ya-11 використовувати толуен та ксилен як джерело карбону та енергії. За результатами досліджень бактерії Desulfotomaculum AR1 на 5-ту добу культивування нагромадили 1,8 г/л біомаси у середовищі з толуеном та 1,2 г/л у середовищі з ксиленом (рис. $1, a$ ).

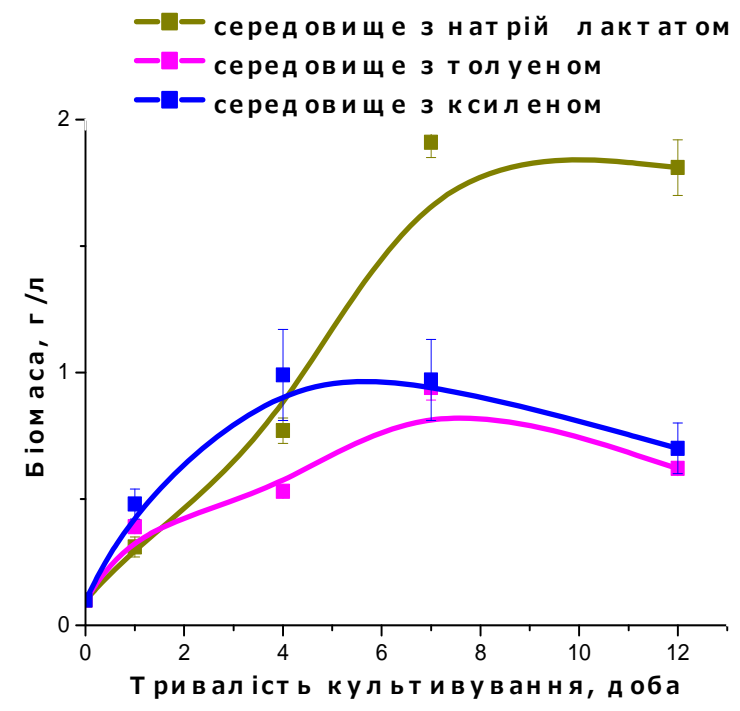

$a$

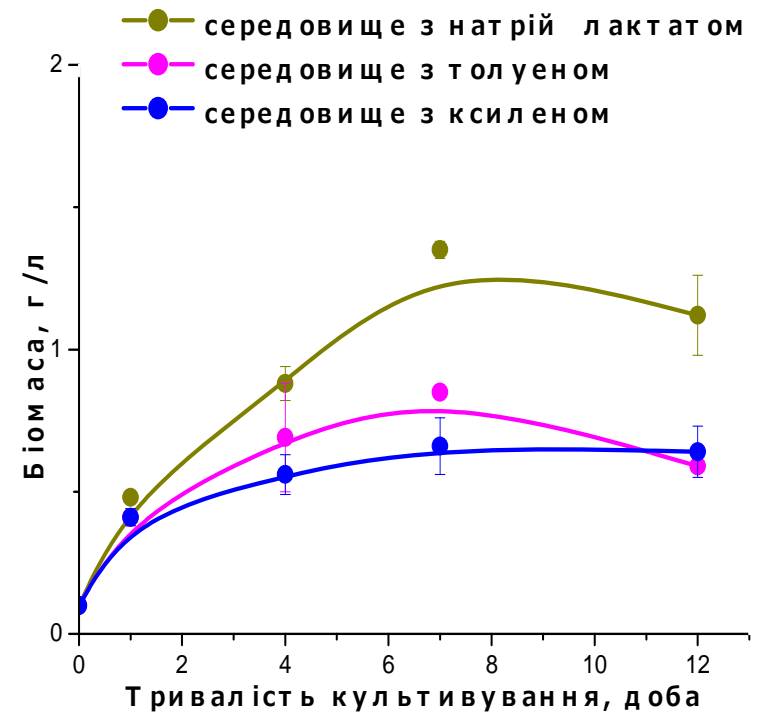

6

Puc. 1. Pict Desulfotomaculum AR1 (a) та D. desulfuricans Ya-11 (б) у середовищі Постгейта С 3 толуеном, ксиленом та натрій лактатом (контроль) як джерелами карбону
Дослідження росту бактерій $D$. desulfuricans Ya-11 у середовищах 3 толуеном та ксиленом показало схожі результати (рис. 1, б). Контролем слугувало середовище 3 натрій лактатом, біомаса досліджуваних бактерій у ньому сягала 3 г/л (рис. 1, $a$, б).

Ефективність відновлення сульфат-йонів досліджуваними бактеріями була достатньо високою у контрольному середовищі (табл. 1). За росту бактерій Desulfotomaculum AR1 та D. desulfuricans Ya-11 у середовищах 3 толуеном/ксиленом ефективність використання сульфату та нагромадження гідроген сульфіду була нижчою, порівняно 3 контрольними показниками, проте у середовищі з толуеном показники ефективності відновлення йонів сульфату обидвома штамами бактерій були вищими за відповідні значення у середовищі 3 ксиленом. Як видно з рис. 1, досліджувані мікроорганізми у середовищі 3 ксиленом також нагромаджували нижчу біомасу. Згідно 3 літературними даними толуен найкраще піддається деструкції мікроорганізмами за анаеробних умов (Gibson, Harwood, 2002), така ж тенденція спостерігається у випадку досліджуваних нами культур сульфатвідновлювальних бактерій.

Стічні води нафтопереробних заводів, целюлозопаперової промисловості, дріжджових заводів, харчових виробництв тощо містять великі кількості йонів сульфату i часто солі важких металів. Внаслідок відновлення бактеріями сульфат-йонів утворюється гідроген сульфід, що здатний осаджувати йони важких металів у вигляді нерозчинних сульфідів. Окрім цього, сульфатвідновлювальні бактерії можуть використовувати $\mathrm{Cr}$ (VI), U (VI), Tc (VI), Pd (II) та інші метали із змінною валентністю як акцептори електронів, переводячи їх у менш токсичні малорозчинні форми (Gudz, 2007).

Реакція конденсації толуену з фумаратом, унаслідок чого утворюється бензилсукцинат, вважається початковим етапом деструкції толуену в бактерій Thauera sp. i Azoarcus sp., a також у сульфатвідновлювальних бактерій. Приєднання фумарату $\epsilon$ загальною реакцією, яку використовують мікроорганізми для активації вуглеводнів, що відбувається також у початкових реакціях 3 іншими метильованими ароматичними речовинами, зокрема 3 ксиленом (Gibson, Harwood, 2002).

На рис. 2 представлено результати дослідження росту сульфатвідновлювальних бактерій Desulfotomaculum AR1 (рис. 2,a) та $D$. desulfuricans Ya-11 (рис. 2, б) у середовищах 3 ксиленом і толуеном за наявності/відсутності у середовищі культивування фумарату. Контролем слугували середовища 3 натрій лактатом 3/без фумарату. Біомаса бактерій у середовищі $з$ толуеном та фумаратом удвічі перевищувала значення біомаси за відсутності фумарату, за культивування як бактерій Desulfotomaculum AR1, так і D. desulfuricans Ya-11 (рис. 2, $а$, б).

За культивування бактерій у середовищі 3 ксиленом фумарат також стимулював ріст мікроорганізмів. У середовищі 3 толуеном/ксиленом без фумарату бактерії нагромадили однакову біомасу (близько 1,5 г/л). Найкращий ріст досліджуваних бактерій спостерігали у середовищі 3 досліджуваною аромосполукою, фумаратом та сульфатом.

Ефективність використання фумарату у середовищі 3 толуеном бактеріями Desulfotomaculum AR1 після семи діб культивування становила понад $90 \%$. Подібні закономірності використання фумарату виявлено за культивування бактерій у середовищі 3 ксиленом як джерелом карбону (рис. 3). У контрольному середовищі, 3 натрій лактатом як донором електронів, фумарату не виявлено вже на 3-тю добу, а в середовищі, де фумарат був єдиним джерелом карбону, ефективність його використання на 7-му добу культивування сягала понад $90 \%$.

За росту у середовищах 3 ароматичними сполуками як акцептори електронів бактерії Desulfotomaculum AR1 використовували сульфат та фумарат. Для підтвердження використання фумарату як донора i акцептора електронів 
Таблиця 1

Відновлення сульфат-йонів бактеріями Desulfotomaculum AR1 та D. desulfuricans Ya-11

за росту у середовищі з ароматичними сполуками

\begin{tabular}{ccccccc}
\hline & \multicolumn{5}{c}{ Середовище культивування } \\
\cline { 2 - 6 } Штам бактерій & \multicolumn{4}{c}{ Постгейта С + толуен } & \multicolumn{4}{c}{ Постгейта С + ксилен } & Постгейта С + натрій лактат (К) \\
\cline { 2 - 6 } & \multicolumn{5}{c}{ Концентрація сульфуровмісних сполук, мМ } \\
\cline { 2 - 6 } & сульфат- & гідроген & сульфат- & гідроген & сульфат- & гідроген \\
& йон & сульфід & йон & сульфід & йон & сульфід \\
\hline Desulfotomaculum AR1 & $11,10 \pm 0,90^{*}$ & $5,08 \pm 0,10^{*}$ & $8,36 \pm 0,05^{*}$ & $2,10 \pm 0,09^{*}$ & $16,08 \pm 0,14$ & $15,65 \pm 0,55$ \\
D. desulfuricans Ya-11 & $6,22 \pm 0,60^{*}$ & $6,06 \pm 0,33^{*}$ & $3,32 \pm 0,11^{*}$ & $1,89 \pm 0,25^{*}$ & $14,72 \pm 0,27$ & $14,67 \pm 0,77$ \\
\hline
\end{tabular}

* $\mathrm{P}<0,05$ - вірогідні зміни, порівняно з контролем.

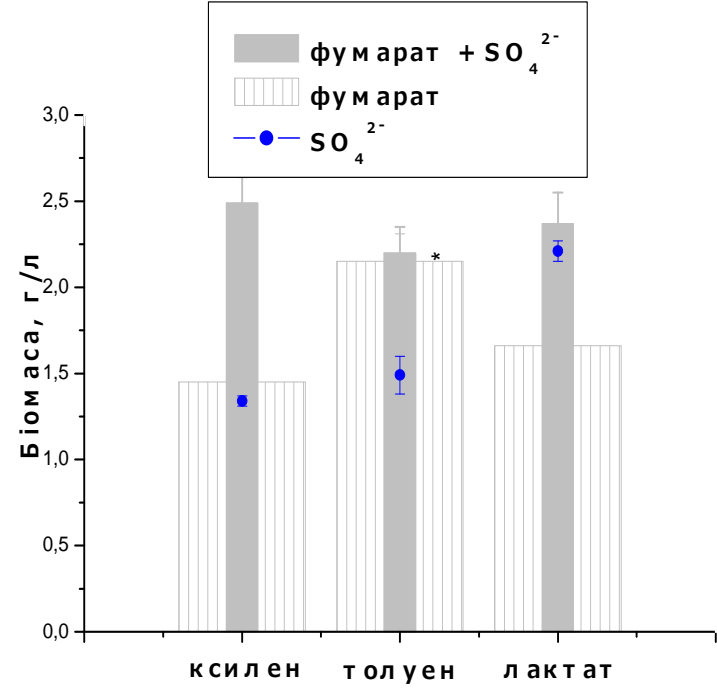

$a$

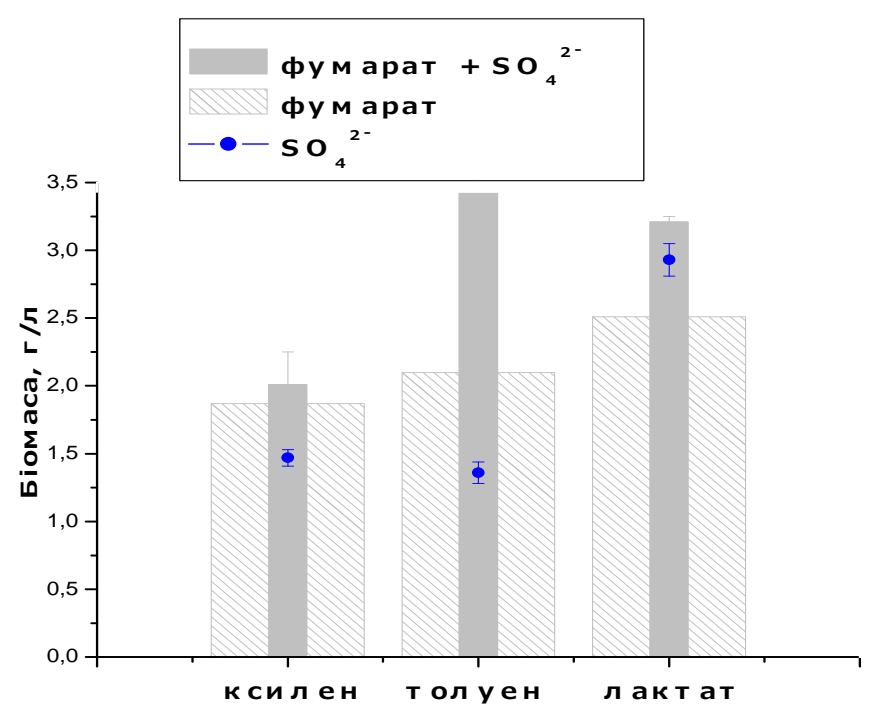

б

Pис. 2. Біомаса бактерій Desulfotomaculum AR1 (a) та D. desulfuricans Ya-11 (б) за росту у середовищі Постгейта C з різними донорами та акцепторами електронів

бактерії Desulfotomaculum AR1 вирощували у середовищі Постгейта C 3 натрій лактатом, фумаратом без йонів сульфату, фумаратом і сульфат-йонами та натрій лактатом, фумаратом i йонами сульфату. Результати дослідження подано у табл. 2.

За використання бактеріями фумарату як акцептора та донора електронів у середовищі виявляють продукти ЦТК. Утворення сукцинату за участю фумаратредуктази $\epsilon$ результатом відновлення фумарату, що підтверджує використання бактеріями фумарату як акцептора електронів (pod red. Lenhelera et al., 2005). За використання фумарату як донора електронів можливе його окиснення до малату (Paulsen, Kroger, Thauer, 1986). За культивування бактерій Desulfotomaculum AR1 у середовищі було виявлено ізоцитрат як продукт перетворення малату. Одержані результати вказують на те, що фумарат може бути використаний бактеріями як джерело карбону, донор та акцептор електронів.

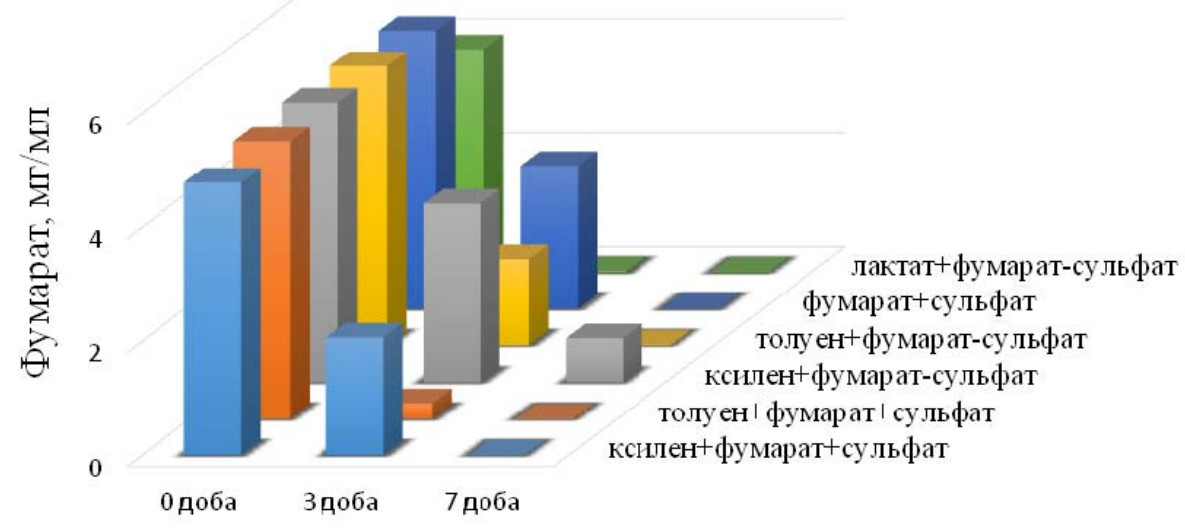

Рис. 3. Використання фумарату бактеріями Desulfotomaculum AR1 за різних умов культивування

Дослідження сульфідогенної активності бактерій Desulfotomaculum AR1 та D. desulfuricans Ya-11 за росту у середовищі 3 толуеном/ксиленом та впливу фумарату представлено в табл. 3. Згідно з отриманими результатами найвищу сульфідогенну активність досліджуваних бактерій виявлено у середовищі з натрій лактатом (62 \%), дещо нижчу у середовищі 3 фумаратом (45\%) як джерелами карбону. Ефективність відновлення сульфату у середовищі 3 лактатом, фумаратом та сульфатом була вдвічі нижчою, ніж у контролі, що свідчить, ймовірно, про пригнічення фумаратом сульфатредукції. 
Таблиця 2

Вміст органічних кислот у середовищі культивування за росту в ньому бактерій Desulfotomaculum AR1

\begin{tabular}{cccc}
\hline Умови культивування & \multicolumn{3}{c}{ Органічні кислоти, мг/мл } \\
\cline { 2 - 4 } & фумарат & сукцинат & ізоцитрат \\
\hline Фумарат + сульфат-йон & $4,50 \pm 0,02^{*}$ & $0,28 \pm 0,15$ & $0,48 \pm 0,21$ \\
Лактат + фумарат & $3,91 \pm 0,004^{*}$ & $0,95 \pm 0,03$ & $0,72 \pm 0,06$ \\
Лактат + фумарат + сульфат-йон & $4,54 \pm 0,12^{*}$ & $0,81 \pm 0,14$ & $0,89 \pm 0,07$ \\
\hline
\end{tabular}

* Вихідна концентрація фумарату 4,86 мг/мл.

\section{Таблиця 3}

Ефективність використання сульфату бактеріями D. desulfuricans Ya-11 та Desulfotomaculum AR1 за умов культивування у середовищі Постгейта $\mathrm{C}$ з різними донорами та акцепторами електронів

\begin{tabular}{|l|c|c|}
\hline \multicolumn{1}{|c|}{ Умови культивування } & \multicolumn{2}{c|}{ Ефективність використання сульфату бактеріями (\%)* } \\
\cline { 2 - 3 } & Desulfotomaculum AR1 & D. desulfuricans Ya-11 \\
\hline Ксилен + фумарат $+\mathrm{SO}_{4}{ }^{2-}$ & 38 & 17 \\
\hline Ксилен - фумарат $+\mathrm{SO}_{4}{ }^{2-}$ & 34 & 25 \\
\hline Толуен + фумарат $+\mathrm{SO}_{4}{ }^{2-}$ & 31 & 26 \\
\hline Толуен - фумарат $+\mathrm{SO}_{4}{ }^{2-}$ & 54 & 45 \\
\hline Фумарат $+\mathrm{SO}_{4}{ }^{2-}$ & 45 & 35 \\
\hline Лактат + фумарат $+\mathrm{SO}_{4}{ }^{2-}$ & 37 & 61 \\
\hline Лактат $+\mathrm{SO}_{4}{ }^{2-}$ (контроль) & 62 & \\
\hline
\end{tabular}

* Вихідна концентрація сульфату 24 мМ.

Ефективність використання сульфату Desulfotomaculum AR1 у середовищі з толуеном/ксиленом була вдвічі нижчою від таких показників у контролі. Бактерії D. desulfuricans Ya-11 за росту в середовищі 3 ароматичними сполуками ще менш ефективніше здійснювали відновлення сульфат-йонів порівняно 3 Desulfotomaculum AR1.

Сульфатвідновлювальні бактерії здатні до анаеробної деструкції ароматичних вуглеводнів за наявності сульфату як кінцевого акцептора електронів. Початковими етапами розкладання толуену та деяких інших метильованих ароматичних вуглеводнів $\epsilon$ їхня взаємодія 3 фумаратом. Утворений внаслідок бактерійної сульфатредукції гідроген сульфід здатний осаджувати йони важких металів у вигляді нерозчинних сульфідів.

\section{Висновки}

Внаслідок великого різноманіття ароматичних сполук та активного їх використання людиною очищення довкілля від ароматичних сполук $\epsilon$ актуальною проблемою сьогодення. Здатність сульфатвідновлювальних бактерій Desulfotomaculum AR1, виділених із системи очищення стічних вод міста Львова, та D. desulfuricans Ya-11 використовувати ароматичні сполуки групи БТЕК толуен, ксилен та сульфат-йони, робить їх перспективними на етапі біологічного очищення забруднених стоків від цих полютантів.

\section{References}

Baran, I. M, Podopryhora, O.I., Hryshchuk, H. V., Bondar, L. S., Kit, L. Ia., Klym, I. R., Hnatush, S. O., Gudz, S. P. (2003). Ekolohichnyi monitorynh vodoim Yavorivskoho sirkovoho rodovyshcha; mikrobiolohichnyi kontrol [Ecological monitoring of water reservoirs of Yavorivsky sulfur deposit; microbiological control]. Environment and health, 27 (4), 56-62 (in Ukrainian).

Dudnik, S. V., Yevtushenko, M. Yu. (2013). Vodna toksykolohiia: osnovni teoretychni polozhennia ta yikhnie praktychne zastosuvannia [Water toxicology: basic theoretical positions and their practical application]. Kyiv, View of the Ukrainian Phytosociological Center (in Ukrainian).
Gibson, J., Harwood, C. (2002). Metabolic diversity in aromatic compound utilization by anaerobic microbes. Annu. Rev. Microbiol., 56, 345-369.

Gudz, S. P., Peretyatko, T. B., Moroz, O. M., Hnatush, S. O., Klym, I. R. (2011). Rehuliuvannia rivnia sulfativ, sirkovodniu ta vazhkykh metaliv $u$ tekhnohennykh vodoimakh sulfatvidnovliuvalnymy bakteriiamy [Regulation of sulfates, hydrogen sulfide and heavy metals level in technogenic reservoirs by sulfate-reducing bacteria]. Mikrobiol. Z., 73 (2), 33-38 (in Ukrainian).

Halushka, A. A., Peretjatko, T. B., Gudz, S. P. (2007). Bakterii tsyklu sirky ta yikhnia rol u pryrodi [Bacteria of sulphur cycle and their role in the nature]. Visnyk of L'viv univ. Biological series, 43, 61-77 (in Ukrainian).

HOST 26426-85 (1985). Pochvu. Metod opredelenyia ionov sulfata v vodnoy vytiazhke. [GOST 26426-85. Soils. Method of sulfate ions in an aqueous extract determination]. Moscow, Publishing House of Standards, 43-46(in Russian).

Kerem, Z., Bravdo, B., Shoseyov, O., Tugendhaft, Y. (2004). Rapid liquid chromatography- ultraviolet determination of organic acids and phenolic compounds in red wine and must. Journal of Chromatography, A 1052 (1-2), 211-215.

Khomenkov, V. G., Shevelev, A. B., Zhukov, V. G., Zagustina, N. A., Bezborodov, A. M., Popov, V.O. (2008). Orhanyzatsyia metabolycheskykh putei y molekuliarno-henetycheskye mekhanyzmy byoderhadatsyy ksenobyotykov u mykroorhanyzmov [Organization of metabolic pathways and molecular-genetic mechanisms of xenobiotic degradation in microorganisms]. Applied Biochemistry and Microbiology, 44(2), 133-152 (in Russian).

Paulsen, J., Kroger, A., Thauer, R. K. (1986). ATP-driven succinate oxidation in the catabolism of Desulfuromonas acetoxidans. Arch. Microbiol., 44, 78-83.

Pavlenko, M. I., Soroka, Ya. M., Gvozdyak, P. I., Kukhar V. P. (2007). Biodestruktsiia politsyklichnykh aromatychnykh vuhlevodniv [Biological degradation of polycyclic aromatic hydrocarbons]. Catalysis and petrochemistry, 15, 46-62 (in Ukrainian).

Peretyatko, T. B., Hnatush, S. O., Gudz, S. P. (2006) Sulfatvidnovliuvalni bakterii Yavorivskoho sirkovoho rodovyshcha [Sulfate-reducing bacteria from Yavoriv storage lake]. Mikrobiol. Z., 68 (5), 84-91 (in Ukrainian). 
Pirog, T. P., Antonuk, S. O., Sofilkanich, A. P. (2016). Transformatsiia aromatychnykh spoluk u poverkhnevoaktyvni rechovyny Rhodococcus erythropolis IMB AC-5017, Acinetobacter calcoaceticus IMB B-7241 i Nocardia vaccinii IMB B-740 [Transformation of aromatic compounds in a surfactant by Rhodococcus erythropolis IMV AL-5017, Acinetobacter calcoaceticus IMV B-7241 and Nocardia vaccinii IMV B-7405]. Scientific Works of NUFT, 22(1), 7-13 (in Ukrainian).

Postgate, J. R.,1984. The sulfate-reducing bacteria. 2nd ed. Cambridge: Cambridge Univ. press, 199 p.

Salmanov, M. A., Veliyev, M. H., Babashly, A. A., Bektashi, N. R. (2010). Byodehradatsyia khlorsoderzhashchykh aromatycheskykh soedynenyi bakteryiamy, vydelennymy yz Azerbaidzhanskoho poberezhia Kaspyiskoho moria [Biodegradation of halogen structured aromatic associations with bacteria isolated from Azerbaijan costs of Caspian]. Bulletin of the Moscow State Regional University. Series: Natural Sciences, 2, 45-50 (in Russian).
Sovremennaya mykrobyolohyia. Prokaryoty / pod red. Y. Lenhelera, H. Drevsa, H. Shlehelia (2005) [Modern microbiology. Prokaryotes / ed. J. Lengeler, G. Drews, G. Schlegel]. Moscow, Myr, 1 (in Russian).

Sugiyama, M. (2002). Reagent composition for measuring hydrogen sulfide and method for measuring hydrogen sulfide. United States Patent N 6340596.

Sushko, A. R., Dugan, A. M., Zhurahivska, L. R., Marintsova, N. G. (2016). Mikroorhanizmy yak destruktory ta indykatory toksychnosti heterotsyklichnykh spoluk [Microorganisms as a destructors and indicators of toxicity of heterocyclic compounds]. Bulletin of Lviv Polytechnic National University, 841, 249-257 (in Ukrainian).

Verkholiak, N. S., Peretyatko, T. B. (2018). Morfofiziolohichni vlastyvosti sulfatvidnovliuvalnykh bakterii, vydilenykh iz systemy ochyshchennia stichnykh vod m. Lvova [Morphophysiological properties of sulfate-reducing bacteria isolated from the system of Lviv wastewater treatment]. Microbology and biotechnology, 4, 19-29 (in Ukrainian). 